himself: 'But there were also such factors as no longer writing creatively, a sex life that had been for years a barren scratching of the physical urge, and the reality that although he had many good friends, he had never had an intimate relationship' (pp.294-5).

Though implicit in all his fiction and critical writing and increasingly explicit in his autobiographical essays and interviews, Pearson's homosexuality was only tacitly acknowledged within most of his social and professional networks throughout his life. Millar's approach is to try and capture tacit knowledge within the discursive conventions of traditional biography, which begins with family genealogy and ends with funeral eulogies. But Pearson's sexuality defies this narrational arc, indentured as it is to reproductive time. Irrevocably split between in and out, then and now, the temporality of queer life is, as Pearson well knew, tied to recursive structures and simultaneously beset by precociousness and belatedness, distraction and delay, as the title of his memoir 'Beginnings and Endings' makes clear. The movement between tacit and patent sexual understandings, as Sedgwick could advise, is less a problem to be resolved than an inexhaustible textual mechanism that generates erotic effects that are far less containable than the trope of the closet suggests. For evidence of this one need read no further than Pearson's scarcely fictionalized account of his pubescent obsession with flies, not just the flickable button and cloth of other boys' pants but the merest indication of them in the comics and illustrated magazines he later puts in the hands of Coal Flat's disturbed schoolboy Peter Herlihy. It is not what the flies conceal but the display of concealment that sexually wires a young boy to nothing more than 'a vague line which might have been the long line of a shadow caused by the fly . . . a simple ink-stroke . . . that line down the centre of [a boy or a man's] trousers. Sometimes if he was lucky he found two. The thick edge and the thin curving thread near its side' (p.61). Taken from 'School, Heart and Home', an unpublished manuscript written when Pearson was seventeen, this is not the work of a young man who would easily forgo a lifetime in charged proximity to the sexual closet.

\title{
The Invention of New Zealand: Art and National Identity, 1930-1970
}

by Francis Pound. Auckland University Press, Auckland, 2009;

xxi, 425 pp., [80] pp. of plates. ISBN 9781869404147

Reviewed by John Newton

When it comes to New Zealand cultural nationalism, poets, as we know, have a lot to answer for. The prodigious force of Curnow's criticism, and the self-assuredness of the Caxton Press, were two factors in the emergence of a discourse in which poetry came to stand as a synecdoche, not just for 
national literature, but for national culture. Curnow's terms and imperatives were adopted, largely unrevised, by early critics of the visual arts. Moreover, as Peter Tomory complained in 1958, that first generation of visual art critics more often than not had no better qualification than their status as men of letters (Fairburn, McCormick, Brasch). There's a certain 'poetic' satisfaction, then, in observing that our best-ever book about cultural nationalism has just been produced by a professional art-historian.

Not that Francis Pound's The Invention of New Zealand has any illusions about being able to escape from the gravitational field of literature. In the first three chapters, in particular, it is by and large the historiography of literary nationalism which Pound is obliged to traverse and synthesize. However, what Pound achieves once and for all - and he does it with an authority that inspires this kind of confident prediction - is to put to bed the content-over-form naivety which characterized 40 -odd years of nationalist picture-viewing.

It was perhaps to be expected that non-specialist critics like McCormick or Fairburn should have tended to judge art in referential rather than painterly terms: how true was it in subject and style to the harsh realities of New Zealand life? Rather more surprising is that the next generation - represented here chiefly by Tomory, and by Pound's particular bêtes noirs Gordon Brown and Hamish Keith in their successive editions of An Introduction to New Zealand Painting $(1969,1982)$ - should have continued to promulgate the amateur critics' geographical determinism. Since the get-go, ran the nationalist account, there had been painters who responded to the particularities of the new environment (topographic artists - Heaphy, Fox, Kinder - or the gloomy and thus implicitly truthful Van der Velden), and others like the Turneresque Romantics, Gully and Hodgkins, who according to Brown and Keith 'did little more than impose on the New Zealand scene the forms and light of a landscape concept which they had carried with them from Europe' (cited by Pound, p.337). The former were of course duly instated as the canonical precursors of the nationalist painters of the Thirties and Forties - ideally, though, not through a process of direct influence, but rather as independent discoverers of the same essential New Zealand condition. The formal language may have become more refined, but critics like Brown and Keith continued to measure their painters against the yardstick of what Pound calls the 'Regional Real'. Thus a twentieth-century canon of Perkins, McCahon, Woollaston and Angus could assimilate neo-hard-edge painters like Binney, White and (above all) Hanly, while remaining effectively blind to such significant abstract practitioners as Walters and Mrkusich.

But Pound has had the 'harsh clarity of New Zealand light' and its variants squarely in his sights since as far back as 1983. In Frames on the Land: Early Landscape Painting in New Zealand, he showed how 'artistic 
conventions carried to nature determine the way nature is seen' (p.11) a commonsense proposition today, but an eye-opener when Pound first broached it. A topographic painting, for instance, will look matter-of-fact and 'real', whatever landscape it's painted in, because that's what the genre demands - a point made again here with reference to Augustus Earle, who discovered in New Zealand exactly the same 'harsh clarities' as in England, South America, Ceylon and South Africa. Rita Angus isn't just looking at what's in front of her; she's also looking at the stylized naturalism of Grant Wood and Georgia O'Keefe. McCahon's 'Waterfall' paintings may share a subject with William Hodges, but their form derives from the 'zip' paintings of Barnett Newman. And so on. If one effect of what Alan Brunton once called the 'deliberate conceit of remoteness' is that life down here is difficult, lonely and potentially heroic, another is that our representations can be imagined as springing by autochthonous magic from our own local soil. But Pound will have none of it, and his authoritative mapping of the ways that international influences have mediated our various realisms makes it seem astounding that such a conceit was able to go unchecked for so long.

His heroes, of course, in addition to postnationalist contemporaries like Killeen, are those painters of the mid-century who were excluded by the nationalist hegemony. Walters and Mrkusich never doubted that paintings are made, not from landscape, but from paint. To see their 'ultra modern' work of the Forties and Fifties in company with the McCahons and Woolastons of the same period is to be reminded all over again that the more glaring the governing paradigm, the deeper the shadow it throws. Pound's aim primarily is to disarticulate the nationalist narrative; its mission is critique. But its spirited account (indebted, the author acknowledges, to Michael Dunn) of Walters' discovery, via Theo Schoon, of Maori rock art, and his progressive sublimation of its lessons through the phases of his mature abstraction, is a major affirmative consequence of the work's critical ground-clearing.

Not that such a critique can avoid throwing the odd shadow of its own. One name not to appear in the index is that of Leo Bensemann, whose unstable hybrids of South Island realism and Yellow Book head-trip confound categories that the nationalists preferred to keep separate (A forthcoming book by Peter Simpson, and accompanying retrospective, promises to be fascinating). And there are certain limitations inherent in the book's implacable formalism. This book has its origins in that bracing moment in the early 1980s when the critics associated with And, and later Splash and Antic, first injected the energies of poststructuralism into a critical culture which had been resting comfortably on its nationalist and realist assumptions. The Invention of New Zealand shares its title with a ground-breaking essay by Roger Horrocks from And (1983), and in a sense, as Pound acknowledges, his monumental book is a summation of the anti-realist critique initiated in 
that moment by Horrocks, Simon During, Leigh Davis, Alex Calder, Wystan Curnow and others. Like most of that initial wave of poststructuralist work, Pound's analysis deconstructs more willingly than it historicizes. It's a critique, then, of rhetoric and representations, which seldom engages deeply with their historical contexts. And though it analyzes with great panache the ways in which painting is mediated by painting itself, it has relatively little to say about painting's mediation by gender and sexuality, and by anxieties of conquest. A 'big' book in many respects, its historicism is not quite as 'thick' as it might at first appear, and while it stands a summation of a lot of recent, sceptical work, it by no means addresses all the key problems that have occupied critics of the mid-century over the last couple of decades.

That said, however, The Invention of New Zealand is a terrific achievement. Beautifully produced by Auckland University Press - a fat, sturdy hardback with no less than 190 colour reproductions - it's a book entirely worthy of its long gestation, and which is sure to enjoy a long, busy shelf-life to match.

\section{Whare Karakia: Māori Church Building, Decoration and Ritual in Aotearoa New Zealand 1834-1863}

by Richard Sundt. Auckland University Press, Auckland, 2010 xiii, 225 pp. ISBN 9781869404567

Reviewed by Robin Skinner

When Richard Sundt arrived from Oregon in 1997 to lecture on Oceanic Art at Victoria University of Wellington, he had no idea that the outcome of this study leave would be an impressive body of research culminating in Whare Karakia: Māori Church Building, Decoration and Ritual in Aotearoa New Zealand 1834-1863. In Wellington he became aware of the Ōtaki church, Rangiātea (built 1848-51), which had been destroyed by arson two years earlier. This was one of a series of large wooden churches, or whare karakia, built by Māori between 1840-1863 that used a central row of prominent columns for structural support, and which were a supposed amalgam of two disparate traditions: neo-gothic church building and Māori whare structures. This book details the complex circumstances under which this series of large whare karakia developed, discusses the unique circumstances of their creation, considers how they operated liturgically and assesses the varied reasons for their success.

While a great deal of research on nineteenth-century church building in New Zealand has been undertaken, to date no single study has focused upon these churches as a coherent phenomenon. Sundt usefully extends a fragmented body of research on missionary church building to explore the conditions that gave rise to these whare karakia. After initially examining 